\title{
OBITUARY
}

\section{Sir Lionel Whitby}

Sir Lionel Whitby died at the age of 61 in the Middlesex Hospital after an operation on November 24, 1956. A few days later memorial services were held in Cambridge and in London. Obituary notices paid eloquent tribute to his character and talents and to the truly astonishing way in which he won distinction successively as soldier, student, teacher, writer. research worker, administrator, professor, Master of his college, and Vice-chancellor of his university. There were many references also to his unique social gifts, his capacity for friendship, his geniality, and good humour.

When a few days later I was asked to write the obituary notice for this Journal I first read through all that I could find which had already been written about him, and this of course made me feel that anything I could say had already been said better before.

None the less, I welcome the opportunity to write something more about Whitby, for two reasons. In the first place I knew him intimately for more than 30 years: we often stayed in each other's homes. and I counted him as one of my closest friends. And secondly because I think I can say more about his relationship to the Association of Clinical Pathologists than anyone else; it was I who introduced him to our association, and I have discussed its affairs with him on very many occasions.

So I will write chiefly about this, though before beginning on this special theme I would like to give three short quotations from the tributes which have been paid to Whitby by other writers. I have selected them because when I read them I felt that they emphasized something important and were singularly well expressed.

My first quotation is from an obituary notice in The Times of November 26, 1956. After referring to Whitby's many responsibilities as Regius Professor of Physic at Cambridge and Vice-chancellor of the University, it continued in these words: "As chairman of innumerable committees and as principal guest at innumerable dinners, he preserved a calmness and judgment and a lightness of touch which made him persona gratissima at public and private functions alike."

"Persona gratissima"-exactly and profoundly true-and I think Lionel Whitby would have been pleased to know that this would be said of him.

My second quotation is from the moving tribute which was paid by his old friend and colleague. C. J. C. Britton, in the obituary notice in the British Medical Journal $(1956,2,1308)$. I chose these sentences to prepare you for what I am going to say later about Whitby's influence in the Association of Clinical Pathologists.

Dr. Britton wrote: "Whitby was a true and perfect example of a clinical pathologist. He believed that the pathologist should be in close touch with the patient and should apply his knowledge of the science of pathology to the art of medicine. He felt strongly that the complete separation of the pathologist from the clinical side of his work was a retrograde step."

The third and last quotation is from a tribute by another colleague, Dr. Martin Hynes, also published

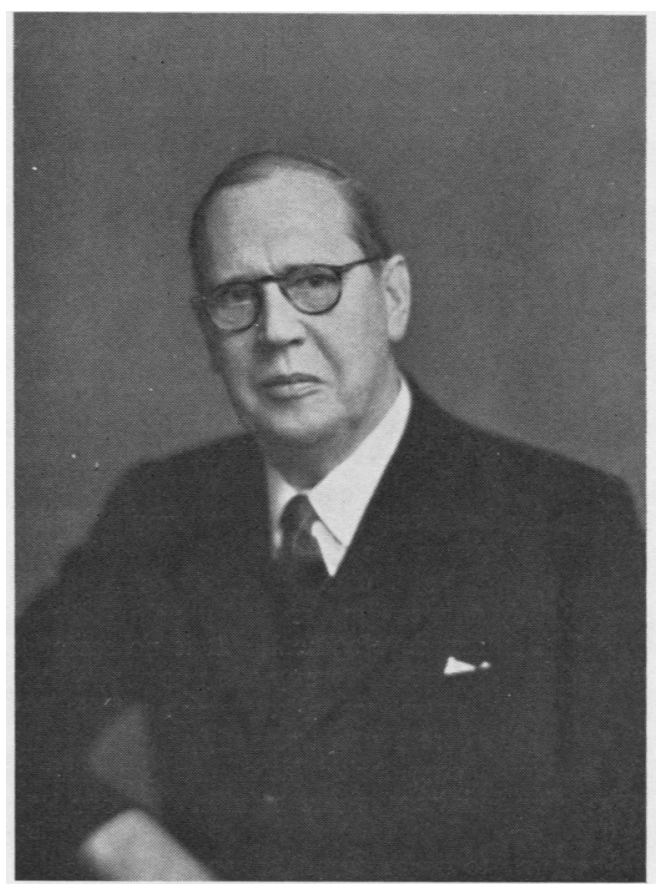

in the British Medical Journal (1956, 2, 1309). After a vivid description of Whitby's laboratory at Middlesex Hospital before the war, of the transfusion service at Bristol during the war, and of his subsequent years in Cambridge, Dr. Hynes recalled Whitby's unvarying kindness as the trait in his character which seemed at first to leave the deepest impression. But, he continued, "The full quality of his mind was always hidden by his modesty, and it was only in retrospect after a conversation that one realized his breadth of knowledge and clarity of vision."

Whitby joined the Association of Clinical Pathologists in 1930, in the fourth year of our existence, at a time when we were still regarded as "suspect" 
by most academic pathologists, at any rate in London. $\mathrm{He}$ was a welcome and valuable recruit because. though only 36 years of age, he had already made his mark as an outstanding clinical pathologist, and in fact had that same year been appointed C.V.O. to reward his services to $\mathrm{King}$ George $\mathrm{V}$ in his serious illness. It was clear from the first that Whitby did not intend to be only a nominal member of our Association. He began to attend our meetings regularly. wrote papers and broadsheets for us, and often took part in our discussions. He was elected to the Council for the first time in 1934, and again after the war served for a second time as a Councillor from 1945-8. He was chosen as President-elect in 1950. and became our President from 1951-4.

It is scarcely necessary to say that within our Association Whitby was greatly respected and regarded by all with warm affection. Even those who did not know him personally formed such an opinion of him from his books and other writings, from his speeches, and general deportment at public functions. On the other hand, those of us who knew him more intimately and worked with him in the Association of Clinical Pathologists soon became aware of his exceptional ability, his wisdom, and the wide range of his knowledge, so that the confidence he had inspired immediately became deepened and strengthened by closer acquaintance. Moreover the honours and distinctions which were showered upon him later did not change the simplicity of his character or affect his loyalty to old friends. Wherever or whenever you met Lionel Whitby, and whoever you might be, you always met the same genial, straightforward, reliable person.

During the last four years in my tenure of office as chairman of the Council of the Association of Clinical Pathologists, I have frequently consulted with Lionel Whitby concerning the policy of our Association and its future development. It is no secret that he was strongly opposed to any attempt at the formation of a faculty or college of pathology at the present time, though he foresaw that something of this nature might be worth considering later. In the meantime he was quite definitely of the opinion that our immediate duty was to foster the development of clinical pathology and to make ourselves worthy of the status we have gained in the National Health Services. I do not know what his opinion would have been with regard to the proposed three categories of membership within the Association of Clinical Pathologists, but in one of my last conversations with him he expressed his whole-hearted approval of the policy of the Council in organizing short refresher courses for pathologists, and he thought the Association should exert its influence to ensure that consultant pathologists were adequately trained in all aspects of clinical pathology.

The Association of Clinical Pathologists has reason to be very grateful to Lionel Whitby. He gave of his best to all that he did for our Association, and we gained immeasurably from his personal influence and reputation. His outstanding contributions to clinical pathology have won him a secure place amongst the great men of our specialty. His unlimited capacity for friendship, his great social gifts. his humour, the merry twinkle in his eye, his boyish sense of fun-these are the qualities his friends will always treasure in their memories of Lionel Whitby.

Cuthrert Dukes.

\section{J. Stewart}

Matthew John Stewart. who died on November 7. 1956, was an Ayrshire man. born at Dalmellington on May 4, 1885. He graduated M.B., Ch.B. with

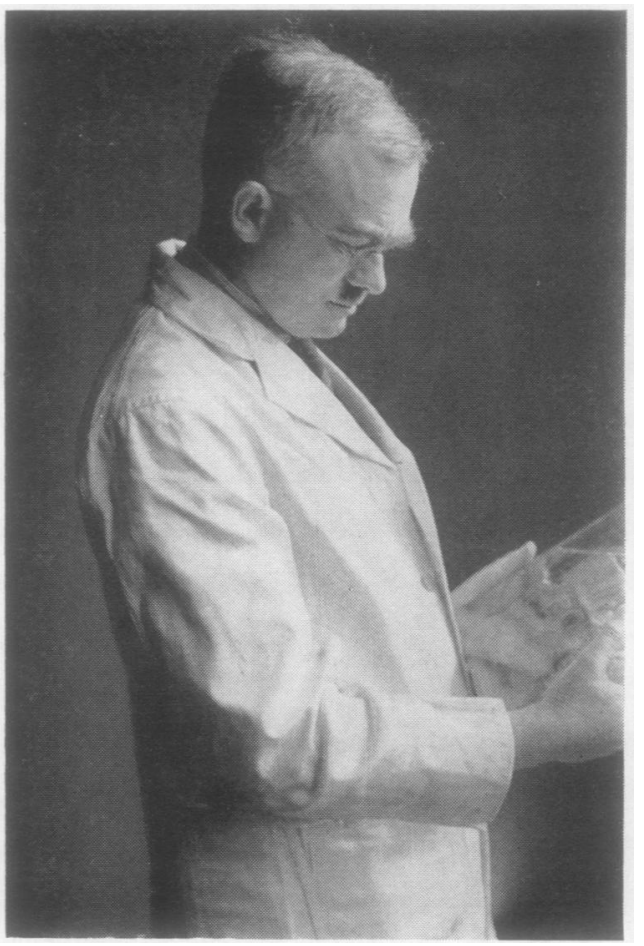

A photograph of Professor Stewart taken in his laboratory in 1932

honours at Glasgow University in 1907. For 33 years he was professor of pathology at Leeds, and for 33 years he was associated with the Journal of Pathology and Bacteriology, first as assistant editor and then, from 1934 to 1956 , as editor. Both as professor and as editor he left a great mark on the world of pathology. In his long tenure of the Leeds chair he built a school of pathology of the highest repute, and in his editorial work he laboured selflessly in creating and in maintaining the highest standards of medical journalism.

Stewart's first posts were in Glasgow with Samson Gemmell and John Brownlee, and he entered pathology under J. H. Teacher at the Royal Infirmary. It was not long, however. before he left Glasgow for 